\title{
Cast of Gharagters
}

THE BAYLEYS

Richard Bayley Sr. (1744-1801)—physician, author of scientific tracts, public health officer.

Catherine Charlton Bayley (d. 1777) - first wife of Richard Bayley, daughter of Rev. Richard Charlton.

Children:

Mary Magdalen Bayley Post (1768-1856), m. Dr. Wright Post, a student of Richard Bayley, in 1790 and bore seven children.

Elizabeth Ann Bayley Seton (1774-1821), m. William M. Seton, merchant, in 1794, and bore five children, who are to be found under The Setons.

Charlotte Amelia Barclay Bayley (1759-1805)—second wife of Richard Bayley, daughter of Helena Roosevelt and Andrew Barclay.

Children:

Charlotte Bayley, called Emma (1779-1805), m. William Craig, relative of Eliza Sadler. 
Richard Bayley Jr. (1781-1815), m. Catherine White in 1812. (Andrew) Barclay Bayley (1783-1811), engaged to Harriet Seton, tried to establish himself as a physician in the West Indies.

Guy Carlton Bayley (1786-1859), m. Grace Roosevelt in 1813, worked first within the Setons' merchant enterprise, then as a physician; son James Roosevelt Bayley converted to Catholicism, was ordained a priest, and served as archbishop of Baltimore.

William Augustus Bayley (1788-1817), m. Jane Smith in 1811.

Helen Bayley (1790-1848), m. Samuel Craig, relative of Eliza Sadler.

Mary Fitch Bayley (1796-1830), m. Robert Bunch.

THE SETONS

William Seton Sr. (1746-1798), merchant.

Rebecca Curson Seton (1746-1775), first wife of William Sr., daughter of Richard Curson Sr., merchant of Baltimore, sister of Anna Maria Curson Seton and Elizabeth Curson Farquhar.

Children:

William Magee Seton (1768-1803), merchant, married Elizabeth Bayley Seton, their children to be found below under William Magee and Elizabeth Bayley Seton.

James Seton (1770-?), merchant, partner to Martin Hoffman, m. Mary Gillou Hoffman (d. 1807), sister of Martin Hoffman; the couple had nine children, often tended by Cecilia Seton.

John Curson (Jack) Seton (ca. 1771-1815), largely unsuccessful merchant, married twice, fathered children often tended by Rebecca Mary Seton.

Henry Seton (1774-?), largely unsuccessful merchant and naval officer. 
Anna Maria Seton Vining (ca. 1775-1802), m. John Middleton Vining in 1790.

Anna Maria Curson Seton (1756-1792), second wife of William Sr., daughter of Richard Curson Sr., merchant of Baltimore, sister of Rebecca Curson Seton and Elizabeth Curson Farquhar.

Children:

Eliza Seton Maitland (1779-1807), m. James Maitland, who abandoned Eliza and their children.

Rebecca Mary Seton (1780-1804), “soul sister” of Elizabeth Bayley Seton.

Mary Seton Hoffman (ca. 1785?-?), lived briefly with Elizabeth Bayley Seton after death of her father, $m$. Martin Hoffman.

Charlotte Seton Ogden (1786-1853), lived briefly with Elizabeth Bayley Seton after death of her father, $\mathrm{m}$. Governeur Ogden (1778-1851).

Henrietta (Harriet or Hatch) Seton (1787-1809), lived for an extended period with Elizabeth Bayley Seton after death of her father.

Samuel Waddington (Sam) Seton (1789-1869), trained as a merchant, later an educator.

Edward Augustus (Ned) Seton (1790-1840s?), trained as a merchant, talented amateur artist, $\mathrm{m}$. Bazilide Balome of Louisiana and established his residence there.

Elizabeth Bayley Seton (1774-1821), m. William Magee Seton (1768-1803) in 1794; the couple had five children, whose stories are told in this book. Readers who do not yet wish to know their fates should avoid the chart below.

Children:

Anna Maria (Anna, Annina) Seton (1795-1812), took initial vows as a Sister of Charity. 
William (Will) Seton II (1796-1868), merchant's clerk, naval officer, m. Emily Prime Seton; the couple's eight children include Monsignor Robert Seton and Helen Seton, who became a Sister of Mercy of New York.

Richard Bayley (Dick) Seton (1798-1823), merchant's clerk, civilian clerk on a naval ship.

Catherine Charlton (Kit, Josephine) Seton (1800-1891), entered Sisters of Mercy of New York in 1846.

Rebecca (Bec) Seton (1802-1816).

FRIENDS，GLERGY，AND SISTERS OF GHARITY

Pierre Babade (1763-1846)-Sulpician priest, professor at St. Mary's, Baltimore, confessor to Elizabeth Seton in the early days of the Emmitsburg community.

The Barrys-James (d. 1808), a Catholic merchant, and Joanna (d. 1811) had two daughters, Mary and Ann, who died in adolescence. The Barrys were confidantes of John Carroll.

Simon Bruté (1779-1839)—Sulpician priest, president of St. Mary's, Baltimore, professor at Mount St. Mary's and spiritual director of Elizabeth Seton, after Seton's death bishop of Vincennes.

The Burkes-Margaret Burke was born in Ireland and educated by Ursulines before abruptly leaving school and marrying. She emigrated to Philadelphia, where her brother Matthew Carey was a successful printer; widowed twice, she served as an assistant to John Dubois at the Mount. Her daughter Maria Burke (also known as Maria Murphy) was one of the first to join Seton's sisterhood.

Charles Carroll (1737-1832)_known as Charles Carroll of Carrollton, only Catholic signer of the Declaration of Independence, United States senator from Maryland, plantation owner, president of the American Colonization Society, and one of the largest slave owners in the country. 
John Carroll (1735-1815)-Jesuit (although the order was suppressed from 1774 to 1814), a founder of Georgetown College, consecrated bishop of Baltimore in 1790 and archbishop in 1808.

The Catons-Richard Caton (1763-1845), a merchant, and wife Mary (Polly) Carroll Caton (1770-1846), daughter of Charles Carroll of Carrollton, were prominent members of Maryland society, as were their four daughters, Marianne, Elizabeth, Louisa, and Emily.

The Harpers-Robert Goodloe Harper (1765-1825), a lawyer, politician, and member of the American Colonization Society, and his wife Catherine Carroll Harper (1778-1861), daughter of Charles Carroll of Carrollton, were prominent members of Maryland society and sent children including Mary Diana, Charles Carroll, Emily, and Elizabeth to be educated at St. Joseph's Academy and Mount St. Mary's.

Jean-Louis Anne Madeleine Lefebvre (John) de Cheverus (1768-1836) - A priest who fled France to serve first in Maine, then in Boston, where he was consecrated the diocese's first bishop in 1810. After Elizabeth's death he was named bishop of Montauban and returned to France.

The Chatards-Pierre (1767-1848)-Born in Saint-Domingue (Haiti) and educated as a physician in France, he became a prominent doctor in Baltimore, married to Marie-Françoise (1777-1863), who was also from Saint-Domingue.

Samuel Sutherland Cooper (1769-1848) - A wealthy sea captain who converted to Catholicism and was eventually ordained a priest; his donation enabled Elizabeth Seton to found the Emmitsburg school and sisterhood.

Jean-Baptiste-Marie (John) David (1761-1841)—A Sulpician priest who fled France, served as professor at both Georgetown College and St. Mary's Baltimore (where he was also acting president), and became the second clerical superior of the Emmitsburg sisterhood. He served as coadjutor of the Bardstown, Kentucky, diocese and, after Seton's death, as bishop; he founded the Sisters of Charity of Nazareth, Kentucky. 
Jean (John) Dubois (1764-1842) - A priest who fled France and joined the Sulpician order in the United States. The first president of Mount St. Mary's and a collaborator of Elizabeth Seton in her school and sisterhood, Dubois later served as bishop of New York.

Louis-Guillaume Valentin (William) Dubourg (1766-1833)Born in Saint-Domingue, Dubourg was ordained a Sulpician priest in France, then fled the Revolution. He served as president of both Georgetown College and St. Mary's, Baltimore, and was the first clerical superior of the sisterhood at Emmitsburg.

Catherine Dupleix-Wife of a sea captain and friend to Elizabeth Seton

The Farquhars-James (ca. 1842-1831), a merchant, in 1774 married Elizabeth Curson (Aunt) Farquhar (ca. 1751-d. after husband, date unknown); the couple were influential within the extended Seton clan and had numerous children (as many as seventeen), one of whom, Eliza, or Zide, was close to Elizabeth Seton.

The Filicchis-Filippo (1763-1816) and Antonio (1764-1847) were merchants based in Livorno, Italy, also known as Leghorn. Filippo, who served as United States consul to Leghorn, married an American, Mary Cowper (1760-1821); the couple died childless. Antonio and his wife Amabilia (1773-1853) had several children.

Margaret George (1787-1868)-Born in Ireland, George emigrated to the United States as a child. After losing much of her family to yellow fever, she moved to Baltimore, where she was educated and married a professor at St. Mary's, Baltimore. Widowed young, she was among the first Sisters of Charity to take vows, served in a number of administrative positions and missions, and founded the American Sisters of Charity of Cincinnati.

Isabella Graham (1782-1814)—Graham became an educator and philanthropist after being widowed with small children. First in her native Scotland and then in New York City, she founded 
schools and charitable institutions including New York's Society for the Relief of Poor Widows with Small Children.

John Hickey (1789-1869)-The first Sulpician to be ordained after training at Mount St. Mary's, Hickey served in a variety of capacities at the Emmitsburg institutions, including as superior of the Sisters of Charity of St. Joseph's from 1829 to 1841.

John Henry Hobart (1775-1830)_Episcopalian minister and author associated with the High Church tradition who, when serving at Manhattan's Trinity Church, spurred Elizabeth Seton's interest in Christianity. Hobart eventually served as Episcopal bishop of New York and founded the General Theological Seminary in New York City.

Michael Hurley (1780-1837)—American-born Hurley was ordained an Augustinian priest in Rome in 1797. After serving in Philadelphia, he was sent to New York to assist William and Matthew O'Brien. Hurley was soon returned to Philadelphia, where he served St. Augustine's parish, participated in Catholic benevolent efforts, and served as vicarius of the Augustinian Province in the United States.

The O'Briens-William O'Brien, an Irish-born Dominican, was pastor to St. Peter's parish, Manhattan, and in his early, energetic years led it out of contention and attracted donations. Matthew O'Brien, likely a relative, became his assistant at the parish and gained praise for his preaching before being accused of serial misconduct.

Ambrose Maréchal (1764-1828)-A Sulpician who fled his native France and served at St. Mary's, Baltimore, and Georgetown, becoming coadjutor bishop of Baltimore. He was consecrated archbishop of Baltimore in 1817.

Cecilia (Veronica) O’Conway (1788-1865)—Daughter of a peripatetic Irish-born translator, Matthias O'Conway, Cecilia was one of the first to join the Emmitsburg community. A confidante of Elizabeth Seton, O'Conway left the Sisters of Charity and became an Ursuline in 1823. 
Eliza Sadler (?-1823)-Irish-born and well-educated, Sadler was the wife and (after 1801) widow of merchant Henry Sadler, who also participated in the poor widows' society, the Orphan Asylum Society, and the House of Industry; relatives of hers married half siblings of Seton.

Julia Scott (1765-1842) - A native of Philadelphia, Julia lived in New York City and befriended Elizabeth Seton during her marriage to the politician Lewis Allaire Scott. She returned to Philadelphia after being widowed, commencing a correspondence with Seton that lasted until the latter's death. Her son, John Morin Scott, became mayor of Philadelphia.

Sarah Startin (1746-1822)-Widow of the successful merchant Charles Startin, she was Elizabeth Seton's godmother and an active participant in Trinity Church and the poor widows' society.

Jean Tisserant (dates unknown)-A French priest who had fled the Revolution and worked in the United Sates as tutor to Catholic families, he became Elizabeth Seton's spiritual director before returning to France.

Rosetta (Rose) White (1784-1841) - Left a widowed mother in her twenties, White was among the first to join the Emmitsburg sisterhood. She served as Elizabeth Seton's first assistant and began missions in Philadelphia and New York; after Seton's death, White was elected to succeed her as Mother, or superior of the sisterhood. 


\section{Elizabeth Seton}


